\title{
IGCP-649 project held 2018 international workshop and field trip in Brisbane, Australia and New Caledonia
}

\author{
Jingsui Yang*, and Tingting Shen
}

Key Laboratory of Deep-Earth Dynamics of Ministry of Natural Resources, Institute of Geology, Chinese Academy of Geological Sciences, Beijing 100037, China; *Corresponding author, E-mail: yangjsui@163.com

The $4^{\text {th }}$ International Ophiolite Workshop of the International Geoscience Programme "Diamonds and Recycled Mantle" (IGCP-649) was successfully held from $4^{\text {th }}$ July to $14^{\text {th }}$ July, in Brisbane (Australia) and New Caledonia (Fig. 1). The workshop was led by Prof. Jingsui Yang from Institute of Geology of CAGS, China and Prof. Jonathan Aitchison from School of Earth and Environment Sciences, The University of Queensland, Australia. After the workshop, attendees participated in a field trip to New Caledonia.

More than 70 scientists from China (including Hong Kong), Australia, New Caledonia, USA and Russia attended this workshop held on $5^{\text {th }}$ to $6^{\text {th }}$ July, 2018, in the University of Queensland, St Lucia Campus, Brisbane, and 60 of them participated in the after-workshop field trip in New Caledonia. At the beginning of the workshop, Prof. Jonathan Aitchison (Head of School, School of Earth and Environmental Sciences, The University of Queensland) made opening speeches welcoming all the participants.

During the workshop, scientists from different countries contributed high quality presentations covering different scientific issues, such as ophiolites and chromitites studies from different locations and different geological settings, ultra-high and high pressure metamorphism in different orogenic belts and fluid and melting process during geological processes and so on. There were 25 oral presentations and 21 poster presentations, and more than half of the presentations were given by enthusiastic young scientists. Prof. Jingsui Yang introduced progress of the IGCP-649 project and reported new studies of diamond and ultra-high pressure unusual mineral selected from peridotites and chromitites, which are strong evidence for deep recycling of crust and mantle in a global system. Prof. Vladimir Shmelev from Institute of Geology and Geochemistry, Ural Branch of RAS (Russia) gave a talk about occurrences of diamond from the Ural-Timan folder belt which was inferred to be the result of ultra-deep subduction. Prof. Liang Liu from Northwest University (China) reported stishovite pseudomorphism found in UHP elcogite from the South Altyn Tagh region, western China, with a minimum peak pressure of the eclogite above 8-9 $\mathrm{GPa}, 800-1000^{\circ} \mathrm{C}$, i.e., exhumed from about $300 \mathrm{~km}$ depth. The presentations were capped off with an excellent introduction to New Caledonia geology by Prof. Jonathan Aitcheson, for which geologists making their first visit to New Caledonia would learn a lot and gain a general knowledge of this area. This Workshop provided an excellent opportunity for scientific communication, especially for young geologists, who could show their achievements in their studies and could communicate with experts in their study area.

New Caledonia is a French Overseas Territory, located in the southwest Pacific, about 1,200 km east of Queensland between approxi- mately $19^{\circ} 30^{\prime}$ and $22^{\circ} 40^{\prime}$ S latitude (Fig. 2a). New Caledonia consists of a principal island - Grande Terre, which is continental in origin; the Loyalty Islands, which are oceanic origin; a number of small, isolated islands that are geologically young, and several reefs (Fig. 2b). New Caledonia separated from Australia about $85 \mathrm{Ma}$ ago, and drifted to the northeast and reached its present position about $55 \mathrm{Ma}$ ago. During the Cenozoic, large parts of New Caledonia experienced a series of marine transgressions, and by the late Eocene nearly all of the island was covered by a thick $(2000 \mathrm{~km})$ sheet of peridotite that was slowly over-thrust during tectonic movement.

The basement of New Caledonia includes rocks that were once accreted to the continental margin of eastern Gondwana. It is overlain by Upper Cretaceous to Eocene sedimentary rocks deposited during Gondwana dispersal (Aitchison et al., 1995a; Cluzel et al., 1995).

The extensive dissected nappe of ultramafic rocks, the New Caledonia Peridotite Nappe, is one of the largest exposed ultramafic bodies on Earth, and once they extended across nearly all of the Grande Terre as well as Pines Island and Belep islands. Although has been reduced by erosion, but it still covers $41 \%$ of the archipelago, and contributes to the considerable economic $\mathrm{Ni}$, $\mathrm{Co}$ and $\mathrm{Cr}$ resources (Pirard et al., 2013). It is interpreted to have been emplaced during collision between an intra-oceanic island arc and the continental fragment that had riftedoff from the eastern margin of Gondwana (Aitchison et al., 1995a). This dominantly ultramafic terrane consists of a southern unit, the"Massif du Sud" and a number of tectonic klippes spread along the West coast of the island. The Massif du Sud represents a crust-mantle section in a nascent arc (Pirard et al., 2013). A range of ages, with clusters around 100 to 77 and 48 Ma has been documented alluding to a complex history. The Cretaceous ages were previously interpreted to represent ophiolite formation, whereas the Eocene ages were considered to reflect thermal overprinting or degassing associated with obduction (Ghent et al., 1994; Aitchison et al., 1995a). Eocene sediments on the island record the arrival and obduction of the structurally underlying Poya basalts comprising dolerite and pillow lava (Aitchison et al., 1995b; Cluzel et al., 1995, 2018).

The famous blueschist to eclogite facies rocks, which crop out in the NE of the island are inferred to have experienced high-P metamorphism in response to the attempted subduction of the crustal basement terranes of New Caledonia beneath the Eocene oceanic island-arc subduction system (Brothers and Blake, 1973; Lillie, 1975; Black, 1977; Ghent et al., 1987; Clarke et al., 1997). Maximum pressure of ca. 24 kbar and temperature of ca. $650{ }^{\circ} \mathrm{C}$ are recorded by relict eclogitefacies assemblages (Clarke et al., 1997; Vitale-Brovarone and Agard, 2013). Peak metamorphic conditions were probably reached during 

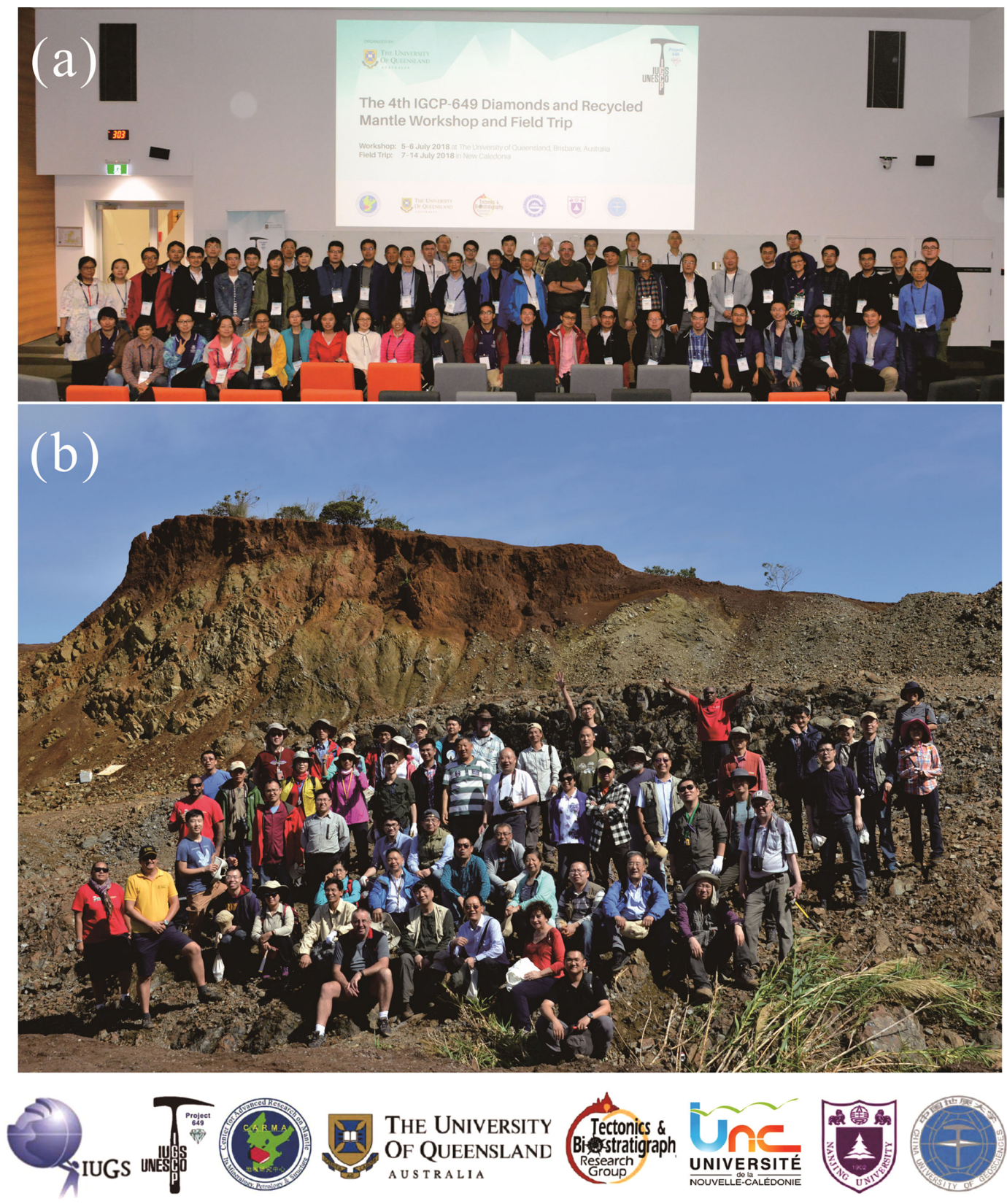

Figure 1. (a) Workshop attendees at the $4^{\text {th }}$ International Ophiolite Workshop of IGCP-649 in Brisbane, Australia. (b) Workshop attendees at the field trip in the Massif du Sud Ophiolite, New Caledonia, SW Pacific.

the early Eocene ( $\sim 4 \mathrm{Ma}, \mathrm{U}-\mathrm{Pb}$ dating of metamorphic zircon overgrowths; Spandler et al., 2005). Mafic eclogites in the Pouebo mélange have Late Cretaceous to Eocene protolith ages and share geochemical affinities with Poya terrane basalts (Cluzel et al., 2001; Spandler et al., 2005). Exhumation of HP-LT metamorphic rocks likely occurred along the subduction channel (Cluzel et al., 2012a; Vitale-Brovarone and Agard, 2013) and took place between $40 \mathrm{Ma}$ and about $34 \mathrm{Ma}$ (Baldwin et al., 2007).

During the field trip, various kinds of peridotite and serpentinite, chromitite, basalt, boninite, blueschist eclogite and rocks with fossils were investigated in detail and many samples were collected. Large amounts of peridotites and chromitites were collected for future mineral separation, petrological and geochemical studies.
The field excursion of the $4^{\text {th }}$ International Workshop in New Caledonia lasted for 8 days from July $7^{\text {th }}, 2018$ to July $14^{\text {th }}, 2018$. Prof. Dominique Cluzel (University of New Caledonia) and Prof. Jonathan Aitchison organized the field investigation and made splendid introductions and explanations. Seventeen stops were designed to show different geological phenomena in order to give attendees a general idea of the geology of New Caledonia. The detailed field route is as follows.

STOP 1 - the Massif du Sud region: The Eocene peridotite nappe dominates in this area, and it is the main outcrop of ultramafic terrane in New Caledonia. The general structure of this ultramafic-mafic sequence is flat-lying. Mantle rocks are mainly harzburgite, and channels of dunite, pyroxenite and gabbro are common within the harzbur- 

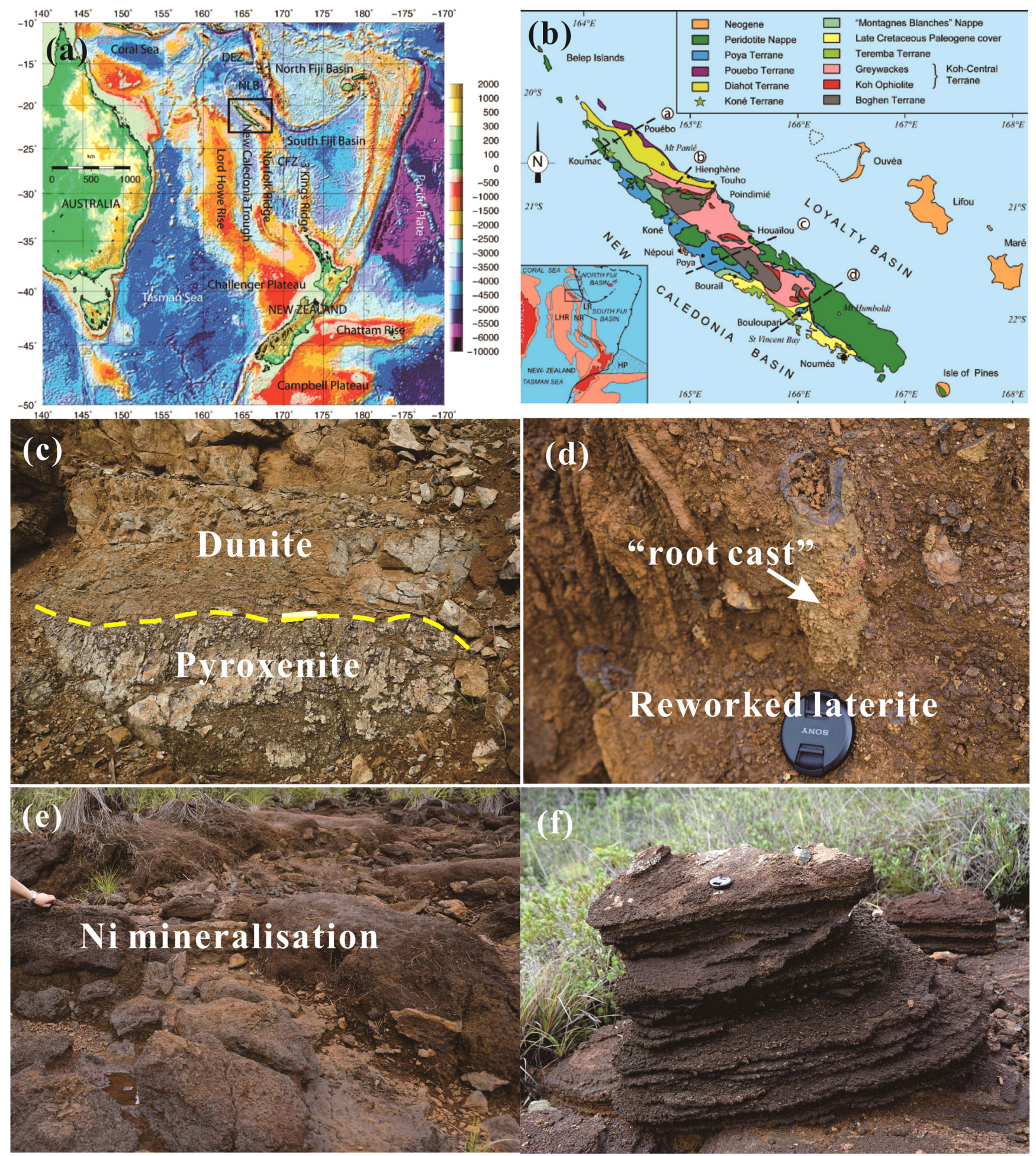

Figure 2. (a) Bathymetric map of the SW Pacific showing the location of New Caledonia, DEZ: D'Entrecasteaux zone, NLB: North Loyalty Basin, CFZ: Cook Fracture Zone (after Smith and Sandwell, 1997; Cluzel et al., 2012a); (b) Tectonostratigraphic terrane map of New Caledonia (after Cluzel et al., 2012a); (c) Contact between dunite and pyroxene, Massif du Sud peridotite; (d) "root cast" in reworked laterite; (e) Ni mineralization in "chutes de Madeleine”, Massif du Sud; (f) Pyroxene cumulate showing differential weathering.

gite (Pirard et al., 2013). Deep levels of the harzburgite could be seen in Yaté. There is an old $\mathrm{Cr}$ mine near Coulée (GR2H). The mine has produced 78,000 metric tons of ore at $47.50 \% \mathrm{Cr}_{2} \mathrm{O}_{3}$ with reserves estimated at 40,000 metric tons. Dunite walls (1-2 m thick) enclose the orebody and are foliated and banded. In some cases, felsic intru- sions and hornblendites could be found as well. In this ophiolite profile, the modal content of orthopyroxene in the harzburgite decrease upwards, and the transition between orthopyroxene-poor harzburgite and dunite units is not always obvious and is highly variable between locations. The dunite zone is estimated to be between 400 to $600 \mathrm{~m}$ 

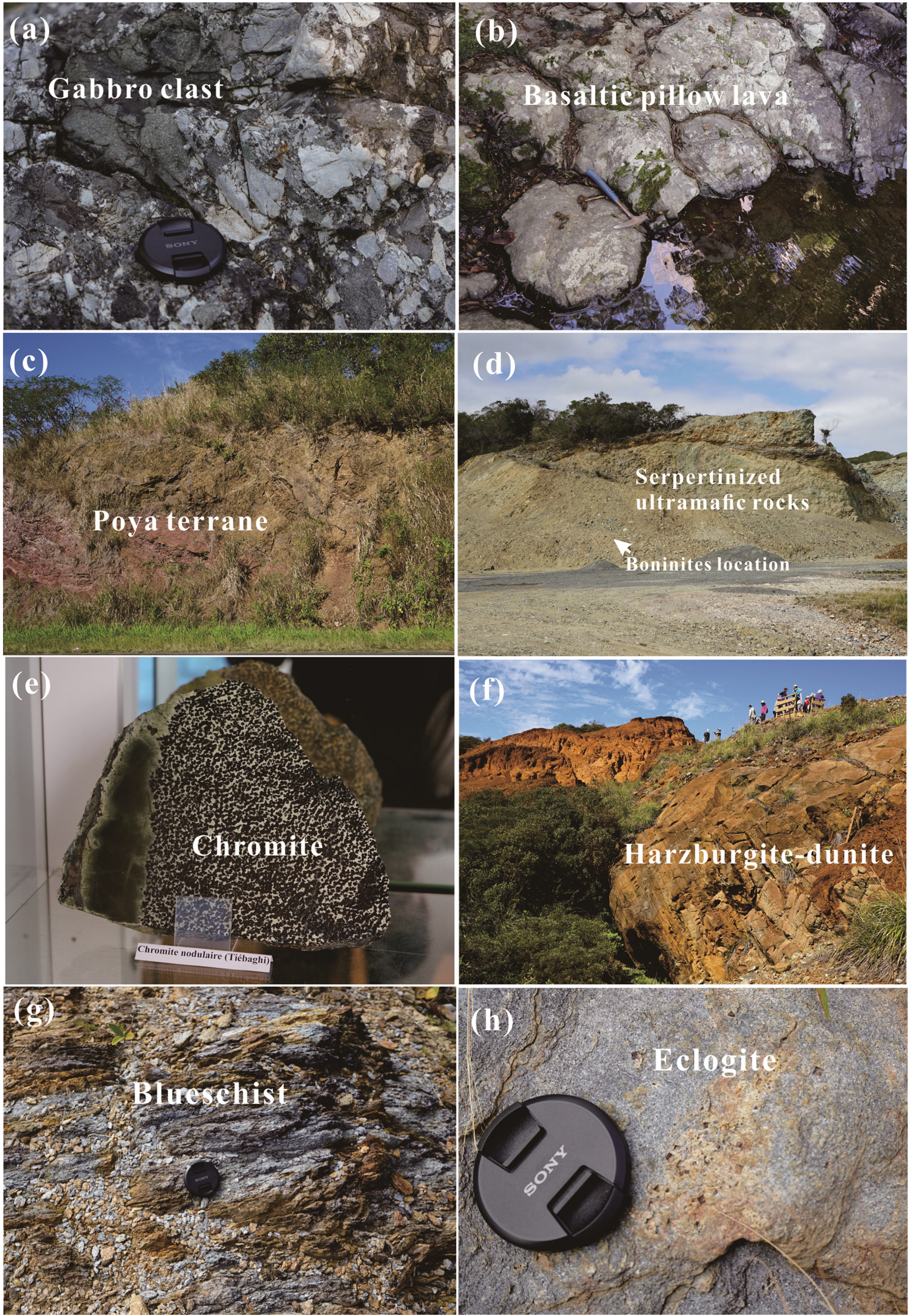

Figure 3. (a) Exotic gabbro clast in Bourail Flysch at Wamutta Creek; (b) Pillow lavas in the Koh terrane exposed at the type locality; (c) Tectonically intercalated basalts and cherts of the Poya terrane exposed north of Bourail; (d) Eocene-aged boninites with twinned clinoenstatite found in this quarry; (e) Chromite ore from Tiébaghi exhibited; (f) Country rocks of chromite showing in open mining pit at Tiébaghi, mainly harzburgite and lherzolite; (g) Buleschist in Col de Amos area; (h) Omphacite-bearing elcogites in the Cape Colnett area. 
thick and could be divided into lower and upper dunite (Pirard et al., 2013).

STOP 2 - Dunite/pyroxenite cumulates (Massif du Sud): In a quarry near col de Mouirange, there is outcrop where participants could observe dunite and pyroxenite cumulates, that should related to the Moho transition zone (MTZ) (Pirard et al., 2013; Secchiari et al., 2016). Rocks in the transition zone have an obvious layering on an outcrop scale and the contact between pyroxenite and dunite is observed commonly (Fig. 2c). Rock types change frequently on a metre to $100 \mathrm{~m}$ scale and in some cases, dunite layer and pyroxenite layer interbedding with each other.

STOP 3 - Fluvio-lacustrine formation (reworked laterite): Iron-rich terrestrial sediments, which are mainly derived from the erosion of an ultramafic regolith, referred to as the Fluvio-lacustrine Formation document the last $25 \mathrm{Ma}$ of the geological history of New Caledonia, with impressive ferruginous rhizocretions or root casts and fossil leaves in the vicinity of Riv. des Pirogues (Folcher et al., 2015). The age of this formation is not tightly constrained yet, but it has recorded several episodes of post-obduction erosion and sedimentary infill preceded and followed by weathering and reactivated erosion (Folcher et al., 2015). The "root cast" (Fig. 2d) might have formed due to chemical or biochemical deposition.

STOP 4 - Chutes de la Madeleine: In this stop we saw waterfalls developed on top of a duricrust, which developed upon reworked laterites. Ni mineralization is abundant, as the relict of weathering crust (laterite) (Fig. 2e). In the hillside to the north there is evidence of former Cr mining activity at the Anna-Madeleine mine, which Cassard et al. (1981) describe as having an orebody that tabular elongated, locally pencil shaped and measuring about $170 \mathrm{~m}$ long by several metres wide.

STOP 5 - Gabbro-websterite/wehrlite cumulates: Here the Moho transition zone is exposed with wehrlite-gabbro-pyroxene from the bottom to the top. The gabbro layers are several metres thick, with diffuse boundaries evolving into plagioclase-bearing wehrlite (Pirard et al., 2013). The pyroxene cumulates are differentially weathered with pyroxene layers left and plagioclase disappearing resulting in obvious layering. Wehrlite layers show poikilitic textures in thin section (Pirard et al., 2013).

STOP 6 - Bourail Flysch: The earliest sedimentary evidence of the beginning of arc-continent collision in New Caledonia. The Poya terrane-derived basaltic (E-MORB) clasts can be seen in Middle to Late Eocene coarse-grained turbidites of upper levels of the Bourail Flysch (Fig. 3a) (Ali and Aitchison, 2000; Maurizot and Cluzel, 2014). The mass-flow deposits in the Wamutta Creek location incorporate detritus derived from the approaching intra-oceanic island arc system.

STOP 7 - Koh terrane (basaltic pillow lavas) (Fig. 3b): Basaltic pillow lavas at this location are mapped as part of the Koh terrane, an entirely different intra-oceanic island arc system of Carboniferous/ Permian age. The few available paleomagnetic data provide somewhat ambiguous results (Ali and Aitchison, 2002). The intra-oceanic nature of these rocks and their Late Carboniferous age determined by the SHRIMP U/Pb zircon method has prompted comparison with the Dun Mountain Ophiolite Belt/Maitai terrane in New Zealand (Aitchison et al., 1998). The geochemistry of these rocks indicates both island arc tholeiitic (85\%) and boninitic compositions (Meffre et al., 1996).

STOP 8 - Poya terrane: This terrane is typical for basalt and red cherty sediments (Fig. 3c). It structurally underlies the ophiolite nappe. The
Poya Terrane is mainly composed of massive and pillow basalts intruded by rare dolerite dikes (Secchiari et al., 2016). The Poya basalts are tectonically interlayered with thin (1-3 m) radiolarian-bearing pelagic sediments, which constrain the timing of basalt eruption between Campanian and Late Paleocene-Early Eocene (Aitchison et al., 1995a; Cluzel et al., 2001).

STOP 9 - Me Maoya Massif: Notable for particularly fresh peridotites. The main rock types are harzburgite and dunite with yellow weathering surfaces.

STOP 10 - Amphibolite body: Immediately after crossing Muéo Pass near Nepoui, a well-layered amphibolite body about $50 \mathrm{~m}$ thick, crops out in a narrow horst bound by steeply dipping normal faults that crosscut the basal serpentinite sole (Cluzel et al., 2012b). The Peridotite Nappe was obducted onto the Poya terrane and formed this HT metamorphic belt on the bottom of serpentinized peridotite, so, we could see amphibolite is conformable with the basal contact of the serpentinite. The amphibolite rock is composed of dark brown hornblende, clinopyroxene, plagioclase, and magnetite.

STOP 11 - Eocene-aged boninites: This kind of boninites are characterized by twinned clinoenstatite crystals and occur in a quarry where boninite is mined for roading aggregate. In the hand specimen, white twinned clinoenstatite crystals could be seen.

STOP 12 - Tiébaghi Cr mine: The Tiébaghi massif consists, from east to west, of harzburgite and dunite, which are overlain by diopside harzburgite and spinel lherzolite locally equilibrated in the plagioclase lherzolite facies (Moutte, 1982). The massif has supplied more than $80 \%$ of New Caledonian chromite production (Auge and Johan, 1988) and was once the largest chromite mine in the world and in 1941 alone, produced about 54,000 tons in a single year. First we stopped at the washing plant where we could see fresh chromitite, next we visited the old mining village, then we went out to the headland at Babouillat where we were able to see lherzolites (Secchiari et al., 2016).

STOP 13 - Blueschist in Col de Amos area: The famous blueschist to eclogite facies rocks have experienced high-P metamorphism in response to the attempted subduction of the crustal basement terranes of New Caledonia beneath the Eocene oceanic island-arc subduction system. These HP-medium-T rocks are subdivide into (1) the Diahot terrane that includes Cretaceous to Eocene sediments and volcanics. The peak metamorphic conditions of PT are about $1.2 \mathrm{GPa}, 550{ }^{\circ} \mathrm{C}$; (2) the Pouébo terrane consisting of metabasic eclogite and glaucophanite, with peak metamorphic conditions of $1.9 \mathrm{GPa}, 590^{\circ} \mathrm{C}$. The blueschist from Diahot terrane contain omphacite, chlorite, lawsonite and glaucophane bearing assemblages, reflecting $\mathrm{PT}$ conditons from $\mathrm{P}=0.7-1.0 \mathrm{GPa}, \mathrm{T}=350-400{ }^{\circ} \mathrm{C}$ to $\mathrm{P}=1.6-1.7 \mathrm{GPa}, \mathrm{T}=550-600{ }^{\circ} \mathrm{C}$ (Fitzherbert et al., 2003). Blueschist in Col de Amos area are enclosed by quartzites and gneiss, containing green fuchsite. In the hand specimen, lawsonite, muscovite and needle glaucophanite could be seen.

STOP 14 - Omphacite-bearing eclogites in the Cape Colnett area: Metabasic eclogites from Pouébo terrane experienced high-P metamorphism of $2.4 \mathrm{GPa}, \sim 600^{\circ} \mathrm{C}$. Metamorphism and deformation were consequent to 44-51 Ma Eocene convergence. Eclogite occurs as metre- to kilometre-scale pods in coarse-grained hydrous mineral rich "glaucophanite" formed during hydration and decompression of the Pouébo terrane. Three types of eclogites are recognized: Type I is dark green and barroisite rich, intensely foliated and has a bulk rock 
composition consistent with a basaltic protolith; Type II is light coloured, weakly foliated and has a bulk rock geochemistry consistent with it being a metamorphosed gabbro cumulate and Type III is found in boulders, tectonically interlayered with Type I eclogite. Three eclogite localities were investigated during this time. (1) Eclogites as lenses included in serpentinites; (2) retrogressed elcogite together with blueschist and (3) relatively fresh eclogite.

STOP 15 - Boghen terrane: A unit we have not encountered thus far. Because of the metamorphism they had experienced these rocks were previously considered to be of pre-Permian age. Zircon age data now allow assignment of a Jurassic age of formation. We investigated dolerite there. There are two kinds of dolerite, one kind is coarse grained and another is fine grained. We collected more samples at this stop.

STOP 16 - Eocene sedimentary rocks: These sediments are part of the Bourail Anticline and contain detrital evidence hinting at the arrival of the allochthonous Poya terrane basalts around the time of initiation of arc-continent collision.

STOP 17 - Upper Triassic bivalve Monotis fossil: Specimens of the Upper Triassic (Norian) bivalve Monotis are exposed in shell-beds along the coastline. It is interesting to observe and contrast with the modern-day fauna. These volcaniclastic rocks are part of the Teremba terrane and are similar to volcaniclastic turbidites of the Murihiku terrane further to the south in New Zealand (e.g., Adams et al., 2009; Campbell et al., 2018). Many fantastic fossils with Monotis were found along the beach.

IGCP-649 is a global research project, aimed to carry out extensive and systematic research on peridotites, chromitites and related materials such as diamond, moissanite and other unusual minerals, from different ophiolites in global orogenic belts, in order to understand the formation and origin of deep-mantle minerals in oceanic lithosphere, the origin of carbon for the ophiolite-hosted diamonds, the evolution of Earth's mantle and the dynamic process of ophiolite emplacement. IGCP-649 project (2015-2020), undertaken by the Center for Advanced Research on the Mantle (CARMA), Institute of Geology, Chinese Academy of Geological Sciences, and was financed and sponsored by UNESCO and IUGS. The $1^{\text {st }}$ Ophiolite Workshop was held in Xining of Qinghai Province, China, in August of 2015. After the workshop, participants undertook a field trip to investigate the Early Paleozoic ophiolite and high-pressure metamorphic belt in the Qilian Mountain. The $2^{\text {nd }}$ Ophiolite Workshop was held in Cyprus in May of 2016. And it included a field trip to investigate the worldrenowned Troodos ophiolite (Yang et al., 2016). The $3^{\text {rd }}$ Ophiolite international workshop was held in Cuba and investigated the famous Mayarí-Baracoa ophiolites and chromitites in Cuba (Yang et al., 2017). This year's Ophiolite Workshop in Australia and New Caledonia attracted more than 70 scientists for coming and the attendees were all impressed with the multitudinous and unusual geological phenomenon in NC.

\section{Acknowledgements}

We appreciate the help of Dr. Dominique Cluzel (University of New Caledonia) for his enthiusiastic and expert guidance in the field. We also thank Prof. Jonathan Aitchison (The University of Queensland, Australia) for the modification of the text.

\section{References}

Adams, C.J., Cluzel, D., and Griffin, W.L., 2009, Detrital-zircon ages and geochemistry of sedimentary rocks in basement Mesozoic terranes and their cover rocks in New Caledonia, and provenances at the Eastern Gondwanaland margin. Australian Journal of Earth Sciences, v. 56, pp. 1023-1047.

Aitchison, J.C., Clarke, G.L., Meffre, S., and Cluzel, D., 1995a, Eocene arc-continent collision in New Caledonia and implications for regional southwest Pacific tectonic evolution. Geology, v. 23, pp. 161-164.

Aitchison, J.C., Meffre, S., and Cluzel, D., 1995b, Cretaceous/Tertiary Radiolarians from New Caledonia. Geological Society of New Zealand Miscellaneous Publication, v. 81A, pp. 70.

Aitchison, J.C., Ireland, T.R., Clarke, G.L., Cluzel, D., Davis, A.M., and Meffre, S., 1998, Regional implications of U/Pb SHRIMP age constraints on the tectonic evolution of New Caledonia. Tectonophysics, v. 299, pp. 333-343.

Ali, J.R., and Aitchison, J.C., 2000, Significance of paleomagnetic data from the oceanic Poya Terrane, New Caledonia on SW Pacific tectonic models. Earth and Planetary Science Letters, v. 177, pp. 153-161.

Ali, J.R., and Aitchison, J.C., 2002, Paleomagnetic-tectonic study of the New Caledonia Koh Ophiolite and the mid-Eocene obduction of the Poya Terrane. New Zealand Journal of Geology and Geophysics, v. 45, pp. 313-322.

Augé, T., and Johan, Z., 1988, Comparative study of chromite deposits from Troodos, Vourinos, North Oman, and New Caledonia ophiolites. In: Boissonnas, J., and Omenetto, P. (Eds.), Mineral Deposits within the European Community. Society for Geology Applied to Mineral Deposits, Special Publication, no. 6, pp. 267-288.

Baldwin, S.L., Rawlings, T. and Fitzgerald, P.G., 2007, Thermochronology of the New Caledonian high pressure terrane: implications for middle Tertiary plate boundary processes in the southwest Pacific. In: Cloos, M., Carlson, W.D., Gilbert, M.C., Liou, J.G., and Sorensen, S.S. (Eds.), Convergent Margin Terranes and Associated Regions: A Tribute to W.G. Ernst. Geological Society of America, Special Papers, v. 419, pp. 117-134.

Black, P.M., 1977, Regional high-pressure metamorphism in New Caledonia: phase equilibria in the Ouégoa district. Tectonophysics, v. 43, pp. 89-107.

Brothers, R.N., and Blake, M.C., 1973, Tertiary plate tectonics and highpressure metamorphism in New Caledonia. Tectonophysics, v. 17, pp. 359-391.

Campbell, M.J., Shaanan, U., Rosenbaum, G., Allen, C.M., Cluzel, D., and Maurizot, P., 2018, Permian rifting and isolation of New Caledonia: evidence from detrital zircon geochronology. Gondwana Research, v. 60, pp. 54-68.

Cassard, D., Nicolas, A., Rabinovitch, M., Moutte, J., Leblanc, M., and Prinzhofer, A., 1981, Structural classification of chromite pods in southern New Caledonia. Economic Geology, v. 76, pp. 805-831.

Clarke, G., Aitchison, J.C., and Cluzel, D., 1997, Eclogites and blueschists of the Pam Peninsula, NE New Caledonia: a reappraisal. Journal of Petrology, v. 36, pp. 843-876.

Cluzel, D., Aitchison, J., Clarke, G., Meffre, S., and Picard, C., 1995, Dénudation tectonique du complexe a noyau métamorphique de haute pression tertiaire (Nord de la Nouvelle-Calédonie, Pacifique, France). Données cinématiques, Comptes-Rendus de l'Acadamie des Sciences de Paris. Serie II, v. 321, pp. 57-64.

Cluzel, D., Aitchison, J.C., and Picard, C., 2001, Tectonic accretion and underplating of mafic terranes in the Late Eocene intraoceanic fore-arc of New Caledonia (Southwest Pacific). Geodynamic implications. Tectonophysics, v. 340, pp. 23-60.

Cluzel, D., Maurizot, P., Collot, J., and Sevin, B., 2012a, An outline of the geology of New Caledonia; from Permian-Mesozoic Southeast Gondwanaland active margin to Cenozoic obduction and supergene evolu- 
tion. Episodes, v. 35, pp. 72-86.

Cluzel, D., Jourdan, F., Meffre, S., Maurizot, P., and Lesimple, S., 2012b, The metamorphic sole of New Caledonia ophiolite: ${ }^{40} \mathrm{Ar} /{ }^{39} \mathrm{Ar}, \mathrm{U}-\mathrm{Pb}$, and geochemical evidence for subduction inception at a spreading ridge. Tectonics, v. 31, TC3016. https://doi.org/10.1029/2011TC003085

Cluzel, D., Whitten, M., Meffre, S., Aitchison, J.C., and Maurizot, P., 2018, A reappraisal of the Poya Terrane (New Caledonia): accreted Late Cretaceous-Paleocene marginal basin upper crust, passive margin sediments, and Early Eocene E-MORB sill complex. Tectonics, v. 37, pp. 48-70.

Fitzherbert, J.A., Clarke, G.L., and Powell, R., 2003, Lawsonite-omphacite-bearing metabasites of the Pam Peninsula, NE New Caledonia: evidence for disrupted blueschist-to eclogite-facies conditions. Journal of Petrology, v. 44, pp. 1805-1831.

Folcher, N., Sevin, B., Quesnel, F., Lignier, V., Allenbach, M., Maurizot, P., and Cluzel, D., 2015, Neogene terrestrial sediments: a record of the post-obduction history of New Caledonia. Australian Journal of Earth Sciences, v. 62, pp. 479-492.

Ghent, E.D., Black, P.M., Brothers, R.N., and Stout, M.Z., 1987, Eclogites and associated albite-epidote-garnet paragneisses between Yambe and Cape Colnett, New Caledonia. Journal of Petrology, v. 28, pp. 627-643.

Ghent, E.D., Roddick, J.C., and Black, P.M., 1994, (40)Ar/(39)Ar dating of white micas from the epidote to the omphacite zones, northern New Caledonia; tectonic implications. Canadian Journal of Earth Sciences (Journal Canadien des Sciences de la Terre), v. 31, pp. 995-1001.

Lillie, A.R., 1975, Structures in the lawsonite-glaucophane schists of New Caledonia. Geological Magazine, v. 112, pp. 225-240.

Maurizot, P., and Cluzel, D., 2014, Pre-obduction records of Eocene foreland basins in central New Caledonia: an appraisal from surface geology and Cadart-1 borehole data. New Zealand Journal of Geology and Geophysics, v. 57, pp. 300-311.

Meffre, S., Aitchison, J.C., and Crawford, A.J., 1996, Geochemical evolution and tectonic significance of boninites and tholeiites from the
Permo-Triassic Koh Ophiolite, New Caledonia. Tectonics, v. 15, pp. 67-83.

Moutte, J., 1982, Chromite deposits of the Tiebaghi ultramafic massif, New Caledonia. Economic Geology, v. 77, pp. 576-591.

Pirard, C., Hermann, J., and O’Neill, H.S.T.C., 2013, Petrology and geochemistry of the crust-mantle boundary in a nascent arc, Massif du Sud Ophiolite, New Caledonia, SW Pacific. Journal of Petrology, v. 54, pp. 1759-1792.

Secchiari, A., Montanini, A., Bosch, D., Macera, P., and Cluzel, D., 2016, Melt extraction and enrichment processes in the New Caledonia lherzolites: evidence from geochemical and Sr-Nd isotope data. Lithos, v. 260, pp. 28-43.

Smith, W.H.F., and Sandwell, D.T., 1997, Global sea floor topography from satellite altimetry and ship depth soundings. Science, v. 277, pp. 1956-1962.

Spandler, C., Rubatto, D., and Hermann, J., 2005, Late Cretaceous-Tertiary tectonics of the southwest Pacific: insights from $\mathrm{U}-\mathrm{Pb}$ sensitive, high resolution ion microprobe (SHRIMP) dating of eclogite facies rocks from New Caledonia. Tectonics, v. 24, TC3003. https://doi.org/ 10.1029/2004TC001709

Yang, J.S., Pearce, J., and Dilek, Y., 2016, Probing the troodos ophiolite: IGCP-649 workshop and field excursion held in Agros-Cyprus. Acta Geologica Sinica (English Edition), v. 90, pp. 1041-1044.

Yang, J.S., Qiu, J., and Llanes Castro, A.I., 2017, Report on the Third IGCP-649 International Workshop on the Mayarí-Baracoa Ophiolites and Chromitites, Cuba. Acta Geologica Sinica (English Edition), v. 91, pp. 2305-2309.

Vitale Brovarone, A., and Agard, P., 2013, True metamorphic isograds or tectonically sliced metamorphic sequence? New high-spatial resolution petrological data for the New Caledonia case study. Contributions to Mineralogy and Petrology, v. 166, pp. 451-469. 